\title{
Citridones, New Potentiators of Antifungal Miconazole Activity, Produced by Penicillium sp. FKI-1938
}

II. Structure Elucidation

Takashi Fukuda, Hiroshi Tomoda, Satoshi Ōmura

Received: December 28, 2004 / Accepted: May 11, 2005

(C) Japan Antibiotics Research Association

\begin{abstract}
The structures of citridones A, B, B' and C, new potentiators of miconazole activity against Candida albicans produced by Penicillium sp. FKI-1938, were elucidated by various spectroscopic analyses including UV, NMR, and MS and degradation experiments. Although citridones $\mathrm{B}$ and $\mathrm{B}^{\prime}$ were isolated as a mixture, each structure was also elucidated, indicating that they exist in equilibrium of hemiacetal epimerization. Citridones A, B and $\mathrm{B}^{\prime}$ have a similar phenylfuropyridone moiety.
\end{abstract}

Keywords citridones, phenylfuropyridone, Penicillium, anti-infective, azole potentiator

\section{Introduction}

During the course of screening for potentiators of antifungal miconazole activity, new citridones $\mathrm{A}, \mathrm{B}, \mathrm{B}^{\prime}$ and $\mathrm{C}$ (Fig. 1) were isolated from the culture broth of Penicillium sp. FKI-1938. The fermentation, isolation and their biological properties are described in the preceding paper [1]. We report herein the structure elucidation of citridones $\mathrm{A}, \mathrm{B}, \mathrm{B}^{\prime}$ and $\mathrm{C}$.

\section{Materials and Methods}

\section{Materials}

Citridones A and $\mathrm{C}$ were purified from the culture broth of Penicillium sp. FKI-1938, but citridones B and B' were isolated as a mixture as described in the preceding paper [1].

\section{General Experimental Procedures}

Optical rotations were recorded with a DIP-370 digital polarimeter (JASCO, Tokyo, Japan). Melting points were measured with a micro melting apparatus (Yanaco, Kyoto, Japan). FAB-MS spectrometry was conducted on a JMSAX505H spectrometer (JEOL, Tokyo, Japan). UV and IR spectra were measured with a DU640 spectrophotometer (Beckman, California, USA) and an FT-210 Fourier transform infrared spectrometer (Horiba, Kyoto, Japan), respectively. The various NMR spectra were measured with a MERCURY plus $300 \mathrm{MHz}$ spectrometer (Varian, California, USA).

\section{Results}

Physico-chemical Properties of Citridones A, B, B' and C

Physico-chemical properties of citridone A, a mixture of

T. Fukuda, S. Ōmura: Kitasato Institute for Life Sciences \& Graduate School of Infection Control Sciences, Kitasato University, 5-9-1 Shirokane, Minato-ku, Tokyo 108-8641, Japan and The Kitasato Institute, 5-9-1 Shirokane, Minato-ku, Tokyo 108-8642, Japan
H. Tomoda (Corresponding author): School of Pharmaceutical Sciences, Kitasato University, 5-9-1 Shirokane, Minato-ku, Tokyo 108-8641, Japan, E-mail: tomoda@lisci.kitasato-u.ac.jp 


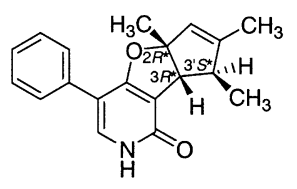

Citridone A

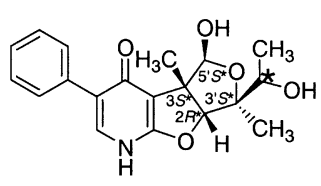

Citridone B

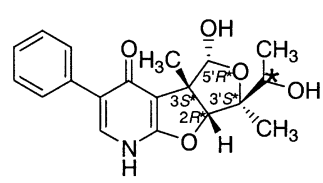

Citridone B'

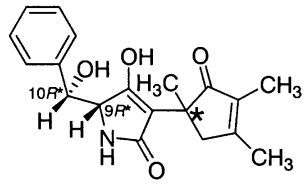

Citridone C

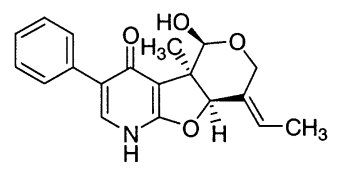

CJ-16,173

Fig. 1 Structures of citridones, A, B, B', C and CJ-16,173.

Table 1 Physico-chemical properties of citridones $A, B+B^{\prime}$ and $C$

\begin{tabular}{|c|c|c|c|}
\hline & Citridone A & Citridones $\mathrm{B}+\mathrm{B}^{\prime}$ & Citridone C \\
\hline Appearance & white needle & white needle & pale yellow amorphous \\
\hline Melting point & $172 \sim 175^{\circ} \mathrm{C}$ & $168 \sim 170^{\circ} \mathrm{C}$ & - \\
\hline$[\alpha]_{D}^{25}$ & $-1.6\left(c 0.1, \mathrm{CH}_{3} \mathrm{OH}\right)$ & $+102.4\left(\mathrm{c} 0.1, \mathrm{CH}_{3} \mathrm{OH}\right)$ & $-74.4\left(c 0.1, \mathrm{CH}_{3} \mathrm{OH}\right)$ \\
\hline Molecular formula & $\mathrm{C}_{19} \mathrm{H}_{19} \mathrm{NO}_{2}$ & $\mathrm{C}_{19} \mathrm{H}_{21} \mathrm{NO}_{5}$ & $\mathrm{C}_{19} \mathrm{H}_{21} \mathrm{NO}_{4}$ \\
\hline Molecular weight & 293 & 343 & 327 \\
\hline \multicolumn{4}{|c|}{ HR-FAB-MS $m / z(M+H)^{+}$} \\
\hline Calcd & 294.1493 (for $\mathrm{C}_{19} \mathrm{H}_{20} \mathrm{NO}_{2}$ ) & 344.1497 (for $\mathrm{C}_{19} \mathrm{H}_{22} \mathrm{NO}_{5}$ ) & $328.1549\left(\right.$ for $\mathrm{C}_{19} \mathrm{H}_{22} \mathrm{NO}_{4}$ ) \\
\hline Found & 294.1493 & 344.1506 & 328.1546 \\
\hline$U V \lambda_{\max }^{\mathrm{CH}_{3} \mathrm{OH}} \mathrm{nm}(\varepsilon)$ & $205(9,800), 246(10,700)$ & $207(21,000), 233(18,900)$ & $203(16,900), 233(11,800)$ \\
\hline \multirow[t]{2}{*}{$\mathrm{IR} v_{\max }^{\mathrm{KBr}} \mathrm{cm}^{-1}$} & $2964,2859,1654,1604$ & $3390,2981,2346,1646$ & $3355,2923,1670,1639$ \\
\hline & 1498,1430 & $1596,1475,1455$ & 1452,1392 \\
\hline \multicolumn{4}{|l|}{ Solubility } \\
\hline \multirow[t]{2}{*}{ Soluble } & $\mathrm{DMSO}, \mathrm{CH}_{3} \mathrm{OH}$ & $\mathrm{DMSO}, \mathrm{CH}_{3} \mathrm{OH}$ & $\mathrm{DMSO}, \mathrm{CH}_{3} \mathrm{OH}$ \\
\hline & $\mathrm{CHCl}_{3}, \mathrm{EtOAc}$ & $\mathrm{CHCl}_{3}, \mathrm{EtOAC}$ & $\mathrm{CHCl}_{3}, \mathrm{EtOAc}$ \\
\hline Insoluble & $n$-Hexane, $\mathrm{H}_{2} \mathrm{O}$ & $n$-Hexane, $\mathrm{H}_{2} \mathrm{O}$ & $n$-Hexane, $\mathrm{H}_{2} \mathrm{O}$ \\
\hline
\end{tabular}

citridones $\mathrm{B}$ and $\mathrm{B}^{\prime}$, and citridon $\mathrm{C}$ are summarized in Table 1. All citridones showed very similar UV spectra with absorption maxima at $203 \sim 207 \mathrm{~nm}$ and $233 \sim 246 \mathrm{~nm}$, suggesting the presence of phenylfuropyridone as reported by Sakemi et al. [2]. Absorptions at about 1670 1639 $\mathrm{cm}^{-1}$ in IR spectra suggested the presence of carbonyl groups. Thus similarity in their data indicated that they are structurally related.

\section{Structure of Citridone A}

The molecular formula of citridone A was determined to be $\mathrm{C}_{19} \mathrm{H}_{19} \mathrm{NO}_{2}$ on the basis of HRFAB-MS measurement (Table 1). The ${ }^{13} \mathrm{C}$ NMR spectrum (in $\mathrm{CDCl}_{3}$ ) showed 19 resolved signals, which were classified into three methyl carbons, two methine carbons, seven $s p^{2}$ methine carbons, six (five $s p^{2}$ ) quaternary carbons and one carbonyl carbon by analysis of DEPT spectra. The ${ }^{1} \mathrm{H}$ NMR spectrum (in $\mathrm{CDCl}_{3}$ ) showed three methyl signals, four methine signals, five aromatic signals and one nitrogen proton signal. The connectivity of proton and carbon atoms was established by the ${ }^{13} \mathrm{C}-{ }^{1} \mathrm{H}$ HMQC spectrum as shown in Table 2. Analysis of the ${ }^{1} \mathrm{H}-{ }^{1} \mathrm{H}$ COSY and ${ }^{13} \mathrm{C}-{ }^{1} \mathrm{H}$ HMBC spectra revealed the three partial structures I, II and III (Fig. 2).

The ${ }^{13} \mathrm{C}-{ }^{1} \mathrm{H}$ long range couplings of ${ }^{2} J$ and ${ }^{3} J$ observed in the ${ }^{13} \mathrm{C}-{ }^{1} \mathrm{H}$ HMBC experiments (Fig. 3) gave the following evidence. 1$)$ The cross peaks from $3-\mathrm{H}(\delta 3.26)$ to $\mathrm{C}-3 \mathrm{a}(\delta 113.5), \mathrm{C}-7 \mathrm{a}(\delta 165.2)$ and $\mathrm{C}-6^{\prime}(\delta 26.2)$, from $6-\mathrm{H}(\delta 7.45)$ to $\mathrm{C}-4(\delta 162.4)$ and $\mathrm{C}-7 \mathrm{a}$ and from $6^{\prime}-\mathrm{H}_{3}(\delta$ $1.65)$ to $\mathrm{C}-2(\delta$ 104.1) and $\mathrm{C}-3(\delta$ 56.4) supported the partial structure I. 2$)$ The cross peaks from $9-\mathrm{H}(\delta 7.52)$ to 
Table $2{ }^{1} \mathrm{H}$ and ${ }^{13} \mathrm{C}$ NMR chemical shifts of citridones $\mathrm{A}, \mathrm{B}$ and $\mathrm{B}$ '

\begin{tabular}{|c|c|c|c|c|c|c|}
\hline & \multicolumn{2}{|r|}{ Citridone A } & \multicolumn{2}{|r|}{ Citridone B } & \multicolumn{2}{|c|}{ Citridone B' } \\
\hline & $\begin{array}{l}{ }^{13} \mathrm{C} \text { chemical } \\
\text { shifts (ppm) }{ }^{\mathrm{a}}\end{array}$ & $\begin{array}{l}{ }^{1} \mathrm{H} \text { chemical } \\
\text { shifts }(\mathrm{ppm})^{\mathrm{b}}\end{array}$ & $\begin{array}{l}{ }^{13} \mathrm{C} \text { chemical } \\
\text { shifts }(\mathrm{ppm})^{\mathrm{a}}\end{array}$ & $\begin{array}{l}{ }^{1} \mathrm{H} \text { chemical } \\
\text { shifts }(\mathrm{ppm})^{\mathrm{b}}\end{array}$ & $\begin{array}{l}{ }^{13} \mathrm{C} \text { chemical } \\
\text { shifts }(\mathrm{ppm})^{\mathrm{a}}\end{array}$ & $\begin{array}{l}{ }^{1} \mathrm{H} \text { chemical } \\
\text { shifts }(\mathrm{ppm})^{\mathrm{b}}\end{array}$ \\
\hline $\mathrm{C}-2$ & 104.1 & & 92.2 & $4.87(1 \mathrm{H}, \mathrm{s})$ & 90.2 & $4.83(1 \mathrm{H}, \mathrm{s})$ \\
\hline C-3 & 56.4 & $3.26(1 \mathrm{H}, \mathrm{d}, J=2.0 \mathrm{~Hz})$ & 58.8 & & 58.1 & \\
\hline C-3a & 113.5 & & 110.3 & & 108.4 & \\
\hline C-4 & $162.4^{c}$ & & 165.0 & & 162.0 & \\
\hline$C-5$ & & 124.1 & & & 122.9 & \\
\hline C-6 & 133.8 & $7.45(1 \mathrm{H}, \mathrm{s})$ & 141.0 & $7.49(1 \mathrm{H}, \mathrm{s})$ & 146.0 & $7.74(1 \mathrm{H}, \mathrm{s})$ \\
\hline $\mathrm{C}-7$ & 111.7 & & & & & \\
\hline C-7a & $165.2^{c}$ & & 164.0 & & 166.5 & \\
\hline C-8 & 133.2 & & 134.0 & & 134.4 & \\
\hline C-9 & 127.5 & $7.52(2 \mathrm{H}, \mathrm{m})$ & 129.2 & $7.36(2 \mathrm{H}, \mathrm{m})$ & 129.1 & $7.43(2 \mathrm{H}, \mathrm{m})$ \\
\hline C-10 & 128.5 & $7.38(2 \mathrm{H}, \mathrm{m})$ & 128.6 & $7.35(2 \mathrm{H}, \mathrm{m})$ & 128.4 & $7.35(2 \mathrm{H}, \mathrm{m})$ \\
\hline $\mathrm{C}-11$ & 127.3 & $7.29(1 \mathrm{H}, \mathrm{m})$ & 127.7 & $7.27(1 \mathrm{H}, \mathrm{m})$ & 127.2 & $7.22(1 \mathrm{H}, \mathrm{m})$ \\
\hline $\mathrm{C}-1^{\prime}$ & 126.2 & $5.38(1 \mathrm{H}, \mathrm{t}, J=1.5 \mathrm{~Hz})$ & 18.1 & $1.17(3 \mathrm{H}, \mathrm{d}, J=6.5 \mathrm{~Hz})$ & 17.6 & $1.16(3 \mathrm{H}, \mathrm{d}, J=6.5 \mathrm{~Hz})$ \\
\hline C-2' & 150.5 & & 72.4 & $3.75(1 \mathrm{H}, q, J=6.5 \mathrm{~Hz})$ & 72.6 & $3.72(1 \mathrm{H}, \mathrm{q}, J=6.5 \mathrm{~Hz})$ \\
\hline C-3' & 49.0 & $\begin{array}{l}2.90(1 \mathrm{H}, \mathrm{dq} \\
\quad J=2.0,7.0 \mathrm{~Hz})\end{array}$ & 91.4 & & 88.4 & \\
\hline C- $4^{\prime}$ & 20.2 & $1.29(3 \mathrm{H}, \mathrm{d}, J=7.0 \mathrm{~Hz})$ & 19.6 & $1.08(3 \mathrm{H}, \mathrm{s})$ & 18.9 & $1.08(3 \mathrm{H}, \mathrm{s})$ \\
\hline$C-5^{\prime}$ & 14.7 & $1.72(3 \mathrm{H}, \mathrm{br} . \mathrm{s})$ & 99.5 & $5.59(1 \mathrm{H}, \mathrm{s})$ & 103.4 & $5.54(1 \mathrm{H}, \mathrm{s})$ \\
\hline$C-6^{\prime}$ & 26.2 & $1.65(3 \mathrm{H}, \mathrm{s})$ & 17.3 & $1.47(3 \mathrm{H}, \mathrm{s})$ & 19.8 & $1.46(3 \mathrm{H}, \mathrm{s})$ \\
\hline
\end{tabular}

a) Chemical shifts are shown with reference to $\mathrm{CDCl}_{3}$ as $77.0 \mathrm{ppm}$. b) Chemical shifts are shown with reference to $\mathrm{CDCl} \mathrm{l}_{3}$ as $7.26 \mathrm{ppm}$. c) The assigments may be exchangeable.
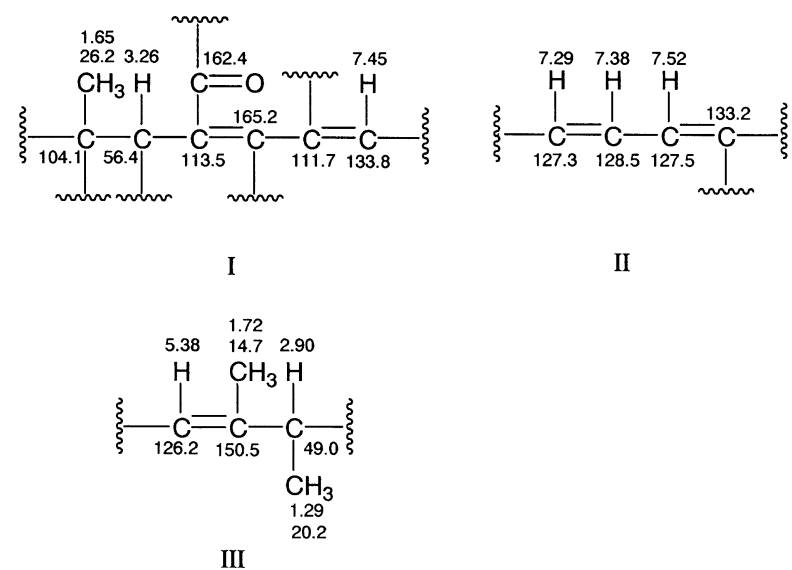

Fig. 2 Partial structures I, II and III of citridone A.

C-11 $(\delta$ 127.3), from $10-\mathrm{H}(\delta 7.38)$ to $\mathrm{C}-8(\delta 133.2)$ and $\mathrm{C}-9(\delta 127.5)$ and from $11-\mathrm{H}(\delta 7.29)$ to $\mathrm{C}-9$ supported the partial structure II. 3$)$ The cross peaks from $1^{\prime}-\mathrm{H}(\delta 5.38)$ to $\mathrm{C}-2^{\prime}(\delta 150.5), \mathrm{C}-3^{\prime}(\delta 49.0)$ and $\mathrm{C}-5^{\prime}(\delta 14.7)$, from $3^{\prime}-$ $\mathrm{H}\left(\delta\right.$ 2.90) to $\mathrm{C}-4^{\prime}(\delta 20.2)$, from $4^{\prime}-\mathrm{H}_{3}(\delta 1.29)$ to $\mathrm{C}-2^{\prime}$ and $\mathrm{C}-3^{\prime}$ and from $5^{\prime}-\mathrm{H}_{3}(\delta 1.72)$ to $\mathrm{C}-1^{\prime}(\delta$ 126.2), C-2'
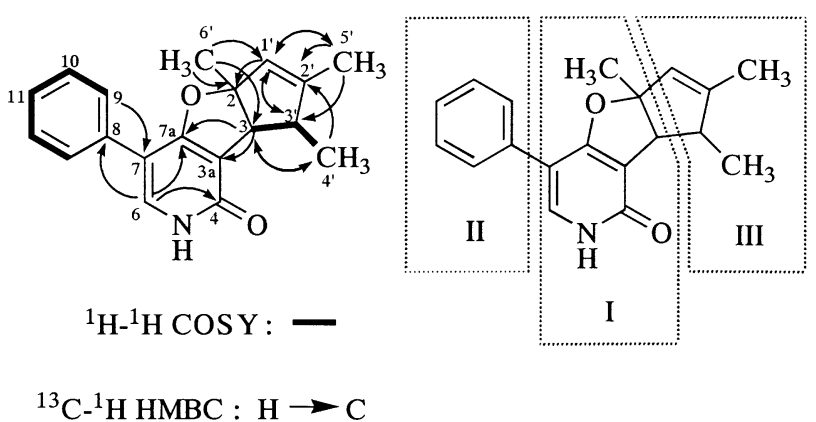

${ }^{13} \mathrm{C}-{ }^{1} \mathrm{H}$ HMBC $: \mathrm{H} \rightarrow \mathrm{C}$

Fig. 3 Key cross peaks observed in ${ }^{1} \mathrm{H}^{-1} \mathrm{H}$ COSY and ${ }^{13} \mathrm{C}^{-}{ }^{-1} \mathrm{H}$ HMBC experiments of citridone $\mathrm{A}$.

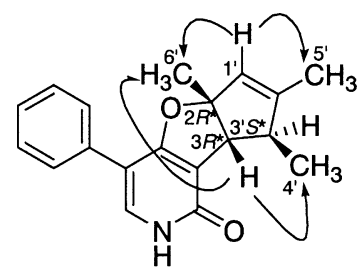

NOE :

Fig. 4 NOE experiments of citridone A. 
and $\mathrm{C}-3$ ' supported the partial structure III. 4) The cross peaks from $6-\mathrm{H}$ to $\mathrm{C}-8$ and from $9-\mathrm{H}$ to $\mathrm{C}-7$ ( $\delta$ 111.7) indicated that the partial structures I and II are linked as shown in Fig. 3. 5) The cross peaks from 3-H to C-1', C-2' and $\mathrm{C}-4^{\prime}$, from $6^{\prime}-\mathrm{H}_{3}$ to $\mathrm{C}-1^{\prime}$, from $1^{\prime}-\mathrm{H}$ to $\mathrm{C}-2$ and $\mathrm{C}-3$, from $3^{\prime}-\mathrm{H}$ to $\mathrm{C}-3$ and from $4^{\prime}-\mathrm{H}_{3}$ to $\mathrm{C}-3$ indicated that the partial structures I and III are joined at C-2 and C-3 as shown in Fig. 3. Thus, the planar structure of citridone $\mathrm{A}$ is shown in Fig. 3. This is reasonable in the molecular formula $\left(\mathrm{C}_{19} \mathrm{H}_{19} \mathrm{NO}_{2}\right)$ and the UV spectra at 205 and $246 \mathrm{~nm}$, which indicated the presence of 4-hydroxy-7phenylfuropyridine as previously reported for CJ-15,696 derivative [2].

The relative configurations of C-2, C-3 and C-3' were determined by NOE experiments. Observation of NOEs from $3-\mathrm{H}$ to $4^{\prime}-\mathrm{H}_{3}$ and $6^{\prime}-\mathrm{H}_{3}$ (Fig. 4) indicated that it forms a cis-geometry. Accordingly, the relative configurations are $2 R^{*}, 3 R^{*}$ and $3^{\prime} S^{*}$. Taken together, the structure of citridone A was elucidated as shown in Fig. 1.

\section{Structure of Citridones B and B'}

Citridones $\mathrm{B}$ and $\mathrm{B}^{\prime}$ were isolated as a mixture, and existed in an equilibrium of $3: 2$ in a solution from the HPLC analysis.

The molecular formula of citridone $\mathrm{B}$ was determined to

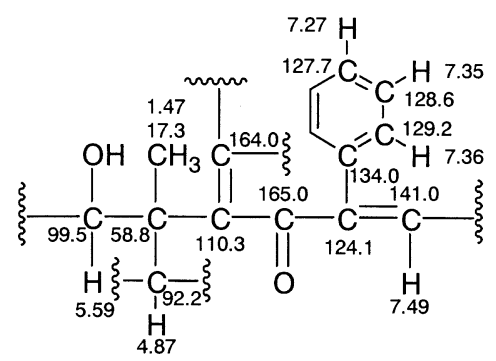

IV

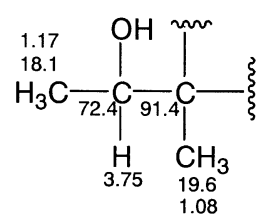

$\mathrm{V}$

Fig. 5 Partial structures IV and $V$ of citridine $B$.

be $\mathrm{C}_{19} \mathrm{H}_{21} \mathrm{NO}_{5}$ on the basis of HRFAB-MS measurement (Table 1). The ${ }^{13} \mathrm{C}$ NMR spectrum (in $\mathrm{CDCl}_{3}$ ) showed 19 resolved signals, which were classified into three methyl carbons, three methine carbons, six $s p^{2}$ methine carbons, six (four $s p^{2}$ ) quaternary carbons and one carbonyl carbon by analysis of DEPT spectra. The ${ }^{1} \mathrm{H}$ NMR spectrum (in $\mathrm{CDCl}_{3}$ ) showed three methyl signals, four methine signals and five aromatic signals, but nitrogen and hydroxy protons were not detected. The connectivity of proton and carbon atoms was established by the ${ }^{13} \mathrm{C}-{ }^{1} \mathrm{H}$ HMQC spectrum as shown in Table 2. Analysis of the ${ }^{1} \mathrm{H}-{ }^{1} \mathrm{H}$ COSY and ${ }^{13} \mathrm{C}-{ }^{1} \mathrm{H}$ HMBC spectra revealed the two partial structures IV and $\mathrm{V}$ (Fig. 5). For citridone B, the cross peaks from $2-\mathrm{H}(\delta 4.87)$ to $\mathrm{C}-3$ ( $\delta 58.8), \mathrm{C}-3 \mathrm{a}(\delta 110.3), \mathrm{C}-7 \mathrm{a}(\delta 164.0), \mathrm{C}-5^{\prime}(\delta$ $99.5)$, and $\mathrm{C}-6{ }^{\prime}(\delta 17.3)$, from $6-\mathrm{H}(\delta 7.49)$ to $\mathrm{C}-4(\delta$ $165.0), \mathrm{C}-5(\delta 124.1), \mathrm{C}-7 \mathrm{a}$ and $\mathrm{C}-8(\delta 124.0)$, from $9-\mathrm{H}(\delta$ $7.36)$ to $\mathrm{C}-5, \mathrm{C}-8$ and $\mathrm{C}-11(\delta 127.7)$, from $10-\mathrm{H}(\delta 7.35)$ to $\mathrm{C}-9(\delta 129.2)$ and $\mathrm{C}-11$, from $5^{\prime}-\mathrm{H}(\delta 5.59)$ to $\mathrm{C}-2, \mathrm{C}-3$ and $\mathrm{C}-3 \mathrm{a}$ and from $6^{\prime}-\mathrm{H}_{3}(\delta 1.47)$ to $\mathrm{C}-2, \mathrm{C}-3, \mathrm{C}-3 \mathrm{a}$ and $\mathrm{C}-$ $5^{\prime}$ were observed in the ${ }^{13} \mathrm{C}-{ }^{1} \mathrm{H}$ HMBC experiments to give the partial structure IV (Fig. 5). The cross peaks from $1^{\prime}-\mathrm{H}_{3}$ $\left(\delta\right.$ 1.17) to C-2' $(\delta 72.4)$ and $\mathrm{C}-3^{\prime}\left(\delta\right.$ 91.4), from $2^{\prime}-\mathrm{H}(\delta$ $3.75)$ to $\mathrm{C}-1^{\prime}(\delta 18.1)$ and $\mathrm{C}-3^{\prime}$ and from $4^{\prime}-\mathrm{H}_{3}(\delta 1.08)$ to $\mathrm{C}-2^{\prime}$ and $\mathrm{C}-3^{\prime}$ were observed in the ${ }^{13} \mathrm{C}-{ }^{1} \mathrm{H}$ HMBC experiments to give the partial structure $\mathrm{V}$ (Fig. 5). The cross peaks from $2-\mathrm{H}$ to $\mathrm{C}-2^{\prime}$ and $\mathrm{C}-3^{\prime}$, from $2^{\prime}-\mathrm{H}$ to $\mathrm{C}-2$
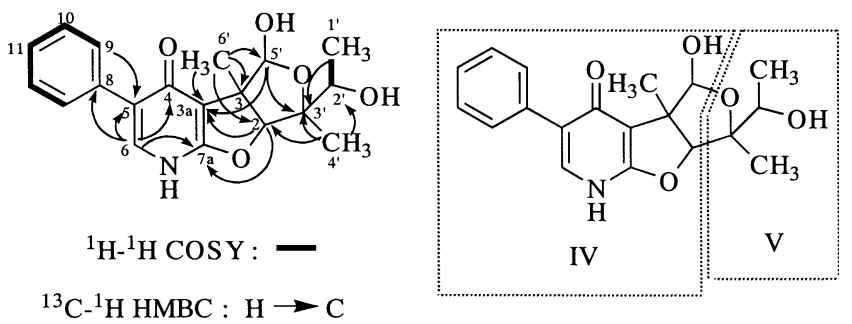

Fig. 6 Key cross peaks observed in ${ }^{1} \mathrm{H}^{1}{ }^{1} \mathrm{H}$ COSY and ${ }^{13} \mathrm{C}^{-}{ }^{1} \mathrm{H}$ HMBC experiments of citridones $B$ and $B^{\prime}$.

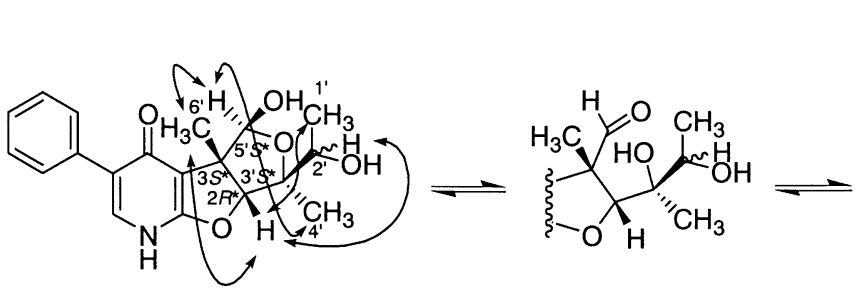

Citridone B

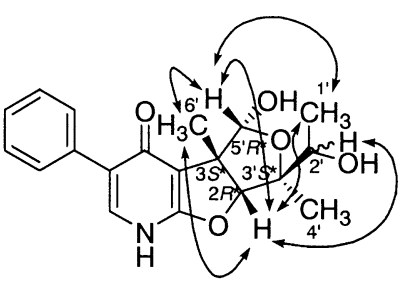

Citridone B'

NOESY :

Fig. 7 NOESY experiments of citridones $B$ and $B^{\prime}$, and the possible intermediate structure in epimerization between citridones $\mathrm{B}$ and $\mathrm{B}^{\prime}$. 
Table $3{ }^{1} \mathrm{H}$ and ${ }^{13} \mathrm{C}$ NMR chemical shifts of citridone $\mathrm{C}$

\begin{tabular}{|c|c|c|}
\hline & \multicolumn{2}{|c|}{ Citridone C } \\
\hline & ${ }^{13} \mathrm{C}$ chemical shifts $(\mathrm{ppm})^{\mathrm{a}}$ & ${ }^{1} \mathrm{H}$ chemical shifts $(p p m)^{b}$ \\
\hline C-1 & 216.9 & \\
\hline C-2 & 132.2 & \\
\hline C-3 & 175.3 & \\
\hline \multirow[t]{2}{*}{ C-4 } & 45.9 & $2.62(1 \mathrm{H}, \mathrm{d}, J=20.0 \mathrm{~Hz})$ \\
\hline & & $3.18(1 \mathrm{H}, \mathrm{d}, J=20.0 \mathrm{~Hz})$ \\
\hline$C-5$ & 47.3 & \\
\hline C-6 & 174.2 & \\
\hline C-7 & 104.3 & \\
\hline C-8 & 169.4 & \\
\hline C-9 & 60.5 & $4.11(1 \mathrm{H}, \mathrm{d}, J=7.0 \mathrm{~Hz})$ \\
\hline C-10 & 75.7 & $4.74(1 \mathrm{H}, \mathrm{d}, J=7.0 \mathrm{~Hz})$ \\
\hline $\mathrm{C}-11$ & 138.9 & \\
\hline C-12 & 126.7 & $7.32(2 \mathrm{H}, \mathrm{m})$ \\
\hline C-13 & 128.1 & $7.25(2 \mathrm{H}, \mathrm{m})$ \\
\hline C-14 & 128.2 & $7.27(1 \mathrm{H}, \mathrm{m})$ \\
\hline C-15 & 7.7 & $1.72(3 \mathrm{H}, \mathrm{s})$ \\
\hline C-16 & 17.4 & $2.04(3 \mathrm{H}, \mathrm{s})$ \\
\hline $\mathrm{C}-17$ & 27.0 & $1.32(3 \mathrm{H}, \mathrm{s})$ \\
\hline
\end{tabular}

a) Chemical shifts are shown with reference to $\mathrm{CDCl}_{3}$ as $77.0 \mathrm{ppm}$. b) Chemical shifts are shown with reference to $\mathrm{CDCl}_{3}$ as $7.26 \mathrm{ppm}$.

and $4^{\prime}-\mathrm{H}$ to $\mathrm{C}-2$ indicated that the partial structures IV and $\mathrm{V}$ are linked at $\mathrm{C}-2$ as shown in Fig. 6. The cross peak from $5^{\prime}-\mathrm{H}$ to $\mathrm{C}-3^{\prime}$ indicated that the partial structure IV is cycled between $\mathrm{C}-3^{\prime}$ and $\mathrm{C}-5^{\prime}$ beyond an oxygen. The number and position of the hydroxyl groups were confirmed by the acetylation and the methylation. Accordingly, the planar structure of citridone $\mathrm{B}$ is shown in Fig. 6. This is reasonable in the molecular formula $\left(\mathrm{C}_{19} \mathrm{H}_{21} \mathrm{NO}_{5}\right)$ and the UV spectra at 207 and $233 \mathrm{~nm}$, which indicated the presence of 4-hydroxy-5-phenylfuropyridine as previously reported for CJ-15,696 derivative [2]. The relative configurations of $\mathrm{C}-2, \mathrm{C}-3, \mathrm{C}-3^{\prime}$ and $\mathrm{C}-5^{\prime}$ were determined by the NOESY experiments (Fig. 7). The cross peaks from $2-\mathrm{H}$ to $1^{\prime}-\mathrm{H}_{3}, 2^{\prime}-\mathrm{H}$, and $6^{\prime}-\mathrm{H}_{3}$ and from $5^{\prime}-\mathrm{H}$ to $4^{\prime}-\mathrm{H}_{3}$ indicated that it forms a cis-geometry. Thus the relative configurations were $2 R^{*}, 3 S^{*}, 3^{\prime} S^{*}$ and $5^{\prime} S^{*}$. However, the relative configuration of $\mathrm{C}-2^{\prime}$ was not defined. Taken together, the structure of citridone $\mathrm{B}$ was elucidated as shown in Fig. 1.

Citridone $\mathrm{B}^{\prime}$ was an epimer at $\mathrm{C}-5^{\prime}$ of citridone $\mathrm{B}$. The cross peaks from $2-\mathrm{H}$ to $1^{\prime}-\mathrm{H}_{3}, 2^{\prime}-\mathrm{H}$ and $6^{\prime}-\mathrm{H}_{3}$ and from $5^{\prime}-$ $\mathrm{H}$ to $2-\mathrm{H}, 2^{\prime}-\mathrm{H}$ and $6^{\prime}-\mathrm{H}_{3}$ in the NOESY experiments (Fig. 7) showed that it forms a cis-geometry. Thus the relative configuration is $5^{\prime} R^{*}$. Finally, the structure of citridone $\mathrm{B}^{\prime}$ was elucidated as shown in Fig. 1.

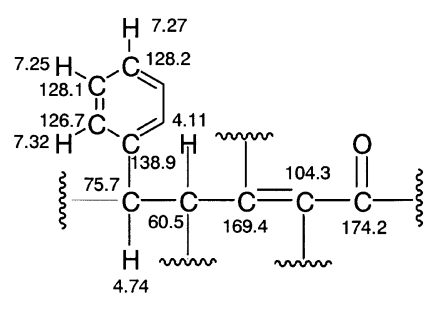

VI

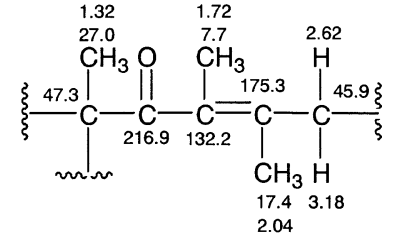

VII
Fig. 8 Partial structures VI and VII of citridone C.

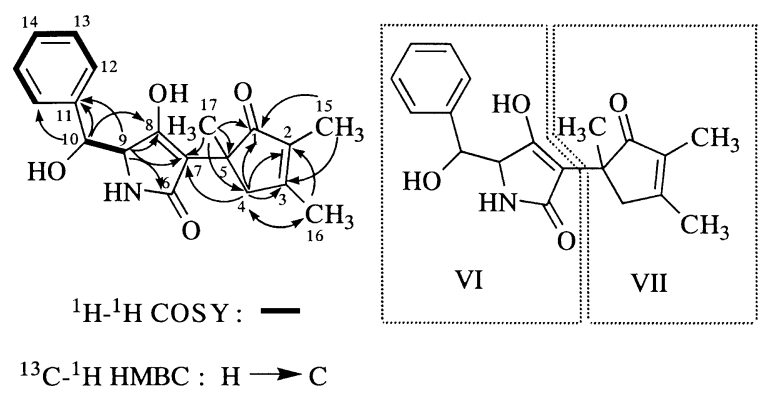

Fig. 9 Key cross peaks observed in ${ }^{1} \mathrm{H}-{ }^{1} \mathrm{H}$ COSY and ${ }^{13} \mathrm{C}^{-1} \mathrm{H}$ HMBC experiments of citridone $\mathrm{C}$.

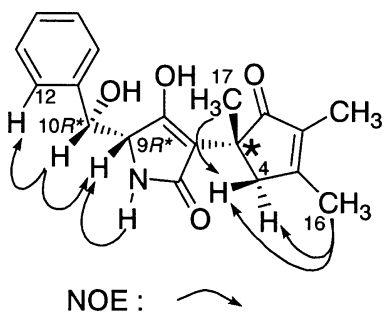

Fig. 10 NOE experiments of citridone C.

Thus, it is plausible that citridones B and $\mathrm{B}^{\prime}$ exist in an equilibrium of hemiacetal epimerization via the aldehyde as the intermediate (Fig. 7).

\section{Structure of Citridone C}

The molecular formula of citridone $\mathrm{C}$ was determined to be $\mathrm{C}_{19} \mathrm{H}_{19} \mathrm{NO}_{4}$ on the basis of HRFAB-MS measurement (Table 1). The ${ }^{13} \mathrm{C}$ NMR spectrum (in $\mathrm{CDCl}_{3}$ ) showed 19 resolved signals, which were classified into three methyl carbons, one methylene carbons, two methine carbons, five $s p^{2}$ methine carbons, six (five $s p^{2}$ ) quaternary carbons and two carbonyl carbons by analysis of DEPT spectra. The ${ }^{1} \mathrm{H}$ NMR spectrum (in $\mathrm{CDCl}_{3}$ ) showed three methyl signals, one methylene signal, two methine signals and five aromatic signals. The connectivity of proton and carbon atoms was established by the ${ }^{13} \mathrm{C}-{ }^{1} \mathrm{H}$ HMQC spectrum as 
Type A

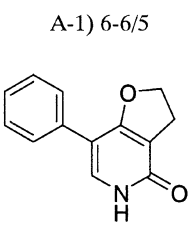

A-3) 6-6/5/5

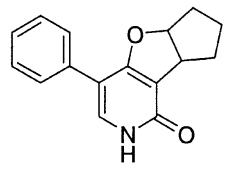

Type B

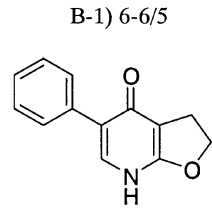

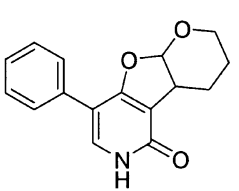

B-2) $6-6 / 5 / 6$
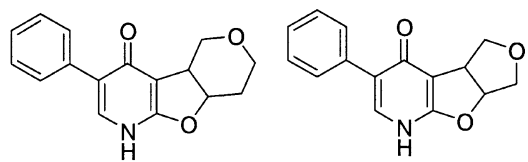

Type C

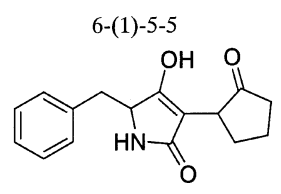

Fig. 11 Structural classification of phenylfuropyridones and related compounds.

shown in Table 3. Analysis of the ${ }^{1} \mathrm{H}-{ }^{1} \mathrm{H}$ COSY and ${ }^{13} \mathrm{C}-{ }^{1} \mathrm{H}$ HMBC spectra revealed the two partial structures VI and VII (Fig. 8).

The ${ }^{13} \mathrm{C}-{ }^{1} \mathrm{H}$ long range couplings of ${ }^{2} J$ and ${ }^{3} J$ observed in the ${ }^{13} \mathrm{C}-{ }^{1} \mathrm{H}$ HMBC experiments (Fig. 9) gave the following evidence. 1$)$ The cross peaks from 9-H $(\delta 4.11)$ to $\mathrm{C}-6(\delta$ $174.2), \mathrm{C}-7(\delta 104.3), \mathrm{C}-8(\delta 169.4), \mathrm{C}-10(\delta$ 75.7) and C11 ( $\delta$ 138.9), from 10-H $(\delta 4.74)$ to $\mathrm{C}-9(\delta 60.5), \mathrm{C}-10, \mathrm{C}-$ 11 and $\mathrm{C}-12(\delta$ 126.7) and from $12-\mathrm{H}(\delta$ 7.32) to $\mathrm{C}-10, \mathrm{C}-$ $11, \mathrm{C}-13(\delta 128.1)$ and $\mathrm{C}-14(\delta$ 128.2) supported the partial structure VI. 2) The cross peaks from $15-\mathrm{H}_{3}(\delta 1.72)$ to $\mathrm{C}-1(\delta 216.9), \mathrm{C}-2(\delta$ 132.2) and $\mathrm{C}-3(\delta$ 175.3), from $16-\mathrm{H}_{3}\left(\delta\right.$ 2.04) to $\mathrm{C}-2, \mathrm{C}-3$ and $\mathrm{C}-4(\delta 45.9)$, from $4-\mathrm{H}_{2}(\delta$ 2.62 and 3.18) to $\mathrm{C}-1, \mathrm{C}-2, \mathrm{C}-3, \mathrm{C}-5(\delta$ 47.3), C-16 $(\delta$ $17.4)$ and $\mathrm{C}-17(\delta 27.0)$, and from $17-\mathrm{H}_{3}(\delta$ 1.32) to $\mathrm{C}-1$, C-4 and C-5 supported the partial structure VII. 3) The cross peaks from $4-\mathrm{H}_{2}$ to $\mathrm{C}-7$ and from $17-\mathrm{H}_{3}$ to $\mathrm{C}-7$ indicated that the partial structures VI and VII are joined at C-5 and C-7. 4) The cross peak from 9-H to C-6 indicated that the partial structure VII is linked to give a cyclic structure beyond nitrogen as shown in Fig. 9. 5) Taking the chemical shifts and molecular formula (Table 1) into consideration, $\mathrm{C}-8$ and $\mathrm{C}-10$ should be hydroxy carbons as shown in Fig. 9.

The relative configurations of $\mathrm{C}-9$ and $\mathrm{C}-10$ were determined by the NOE experiments (Fig. 10). Observation of NOEs from NH $(\delta 5.78)$ to $9-\mathrm{H}$ and from $10-\mathrm{H}$ to $9-\mathrm{H}$ and $12-\mathrm{H}$ indicated that it forms a cis-geometry. Thus, the relative configurations of $\mathrm{C}-9$ and $\mathrm{C}-10$ were $9 R^{*}$ and $10 R^{*}$. The relative configuration of $\mathrm{C}-5$ was not determined by the NOE experiments because it was far from C-9. However, NOEs from $16-\mathrm{H}_{3}$ to $4-\mathrm{H}_{2}$ and from $17-\mathrm{H}_{3}$ to only $4-\mathrm{H}(\delta 2.62)$ were observed as shown in Fig. 10. Thus, the structure of citridone $\mathrm{C}$ was elucidated as shown in Fig. 1.

\section{Discussion}

Eight phenylfuropyridones (or hydroxy-phenylfuropyridines) were reported as antibacterial or antifungal antibiotics from Cladobotryum varium [2 4]. Based on the ring system of the furopyridone moiety, they are classified into the two types as summarized in Fig. 11. Type $\mathrm{A}$ is the phenyl- $\alpha$-furopyridone family containing the A-1 group (66/5 ring system) such as CJ-16,170, CJ-16,196 and CJ16,197 [2], and the A-2 group (6-6/5/6 ring system) such as CJ-16,171 [2]. Citridone A is a member of Type A having a new 6-6/5/5 ring system (A-3 group). Type $B$ is the phenyl$\gamma$-furopyridone family containing the B-1 group (6-6/5 ring system) such as CJ-15,696, CJ-16,169, CJ-16,174 [2], and cladobotryal [5], and the B-2 group (6-6/5/6 ring system) such as CJ-16,173 [2]. Citridones B and B' are members of Type B having a new 6-6/5/5 ring system (B-3 group). Citridone $\mathrm{C}$ has an isolated ring system (Type $\mathrm{C}$ ).

Regarding the chemical shift of the $\mathrm{C}$-2 quaternary carbon for citridone A (A-3 group in Fig. 11), the value (104.1 ppm) seemed very lower than the expected one. However, it was reported that the analogous chemical shift (95.1 ppm) of the C-2 methine carbon for CJ-16,170 (A-1 group in Fig. 11) also showed a lower value [2]. It might be that the C-2 carbons in Type A compounds show lower chemical shifts due to the unexpected reasons. But further experiments such as X-ray crystallography or synthetic approaches are necessary to define this point. Citridones B and $\mathrm{B}^{\prime}$ are illustrated as a pyridone-type structure in Figs. 1, 6 and 7, because $N$-methyl derivative was obtained by methylation of citridone B (data not shown). However, they might co-exist with a pyridinol-type structure because tri$O$-acetyl derivative was obtained by acetylation of citridone B (data not shown).

Thus, citriodnes are found to be a new type of phenylfuropyridones possessing unique ring systems. Their biosynthesis appeared to be related to that of fungal tenellin case [6].

Acknowledgments We wish to thank Ms. Noriko Sato, Ms. Akiko Nakagawa and Ms. Chikako Sakabe, School of Pharmaceutical Sciences, Kitasato University, for measurements of NMR and mass spectra. This study was supported in part by the 21st Century COE Program and Kakenhi 16073215, Ministry 
of Education, Culture, Sports, Science and Technology, Japan.

\section{References}

1. Fukuda T, Yamaguchi Y, Masuma R, Tomoda H, Ōmura S. Citridones, potentiators of antifungal miconazole activity, produced by Penicillium sp. FKI-1938 I. Taxonomy, fermentation, isolation, and biological properties. J Antibiot 58: 309-314 (2005)

2. Sakemi S, Border J, Decosta DL, Dekker KA, Hirai H, Inagaki T, Kim YJ, Kozima N, Sims JC, Sugie Y, Sugiura A, Sutcliffe JA, Tachikawa K, Truesdell SJ, Wong JW, Toshikawa N, Kozima Y. CJ-15,696 and its analogs, new furopyridine antibiotics from the fungus Cladobotryum varium: fermentation, isolation, structural elucidation, biotransformation and antibacterial activities. J Antibiot 55:
6-18 (2002)

3. Breinholt J, Jensen HC, Kjaer A, Olsen CE, Rassing BR, Rosendahl CN, Sotofte I. Cladobotryal: a fungal metabolite with a novel ring system. Acta Chem Scand 52(5): 631-634 (1998)

4. Demuth H, Breinholt J, Rassing BR (Novo Nordisk a/s). New furyl-pyridone compounds useful as fungicides and obtained from the fungus Cladobotryum. WO 9711076 A1, March 27 (1997)

5. Derrick LJC, Huang X. Model studies and first synthesis of the antifungal and antibacterial agent cladobotryal. J Org Chem 69: 1872-1879 (2004)

6. Moore CM, Cox RJ, Duffin GR, O'Hagan D. Synthesis and evaluation of a putative acyl tetramic acid intermediate in tenellin biosynthesis in Beauveria bassiana. A new role for tyrosine. Tetrahedron 54: 9195-9206 (1998) 